\title{
Physiological Changes of Broccoli during Early Postharvest Senescence and through the Preharvest- Postharvest Continuum
}

\author{
Graeme A. King \\ New Zealand Institute for Crop and Food Research, Levin, New Zealand \\ Stephen C. Morris \\ Commonwealth Scientific and Industrial Research Organisation, Division of Horticulture, \\ Sydney, Australia
}

Additional index words. Brassica oleracea Italica group, color, ethylene, quality, respiration

\begin{abstract}
The postharvest senescence of broccoli (Brassica oleracea $\mathrm{L}$. Italica group) was studied immediately after harvest until senescence was essentially completed at $20 \mathrm{C}$. Changes in respiration, ethylene production, and color were determined for florets, branchlets, and heads of three cultivars of field-harvested 'Green Beauty', 'Dominator', and 'Shogun' broccoli. Changes in respiration and ethylene production were also determined for 3 hours of preharvest and 24 hours of postharvest storage using broccoli grown in containers. Carbon dioxide produced from heads of container-grown broccoli and from heads, branchlets, and florets of field-harvested broccoli decreased markedly during the first 12 hours of postharvest storage before stabilizing. The respiratory quotient shifted toward a more oxidative metabolism in parallel with the respiratory decline. Ethylene production during storage showed no consistent relationship to yellowing. However, time until onset of yellowing was broadly related to the basal levels of ethylene production. The maximum storage life at $20 \mathrm{C}$ is $\approx 72$ hours. Branchlets are useful model systems for investigating broccoli senescence.
\end{abstract}

Harvested broccoli comprises a mass of green floral buds (florets) and thick, fleshy flower branchlets or stalks attached to the central plant axis (collectively, the head). The immature floret clusters, together with the branchlets, are usually eaten, and the central axial tissue commonly is discarded. Fresh broccoli is highly perishable, with a storage life of 3 to 4 weeks in air at $0 \mathrm{C}$ (Makhlouf et al., 1989a) and 2 to 3 days in air at 20C (Wang, 1977). As broccoli deteriorates, the head yellows due to degradation of chlorophyll (Wang, 1977). Branchlets and florets lose turgor and become flaccid if water loss is excessive (Brennan and Shewfelt, 1989). Decay commonly occurs on florets, primarily during advanced stages of senescence (Aharoni et al., 1985).

Despite the rapid decline in quality of fresh broccoli, no detailed investigations exist of the physiological changes occurring within the first few hours after harvest. Research on asparagus (another highly perishable crop) has shown that major changes in respiration (King et al., 1990; Lill et al., 1990), N metabolism (Hurst et al., 1993), and gene expression (Davies and King, 1993) occur within $3 \mathrm{~h}$ of harvest. An understanding of early changes is essential for accurately interpreting subsequent postharvest senescence, as crops commonly spend several hours at ambient temperatures while the crop is graded and packaged. In this respect, it is useful to recall (although the point is frequently ignored) that the preharvestpostharvest periods comprise a physiological continuum.

Studies of the physiology of broccoli senescence are complicated by the diversity of tissues present in excised heads. Most studies have used whole heads (Brennan and Shewfelt, 1989; Dedolph et al., 1963; Kasmire et al., 1974; Lebermann et al.,

Received for publication 30 Nov. 1992. Accepted for publication 19 July 1993 G.A.K. acknowledges CSIRO for support to undertake these studies while on study leave to the Sydney laboratory. We thank P. Cornish of the New South Wales Dept. of Agriculture and Fisheries for assistance during this research. The cost of publishing this paper was defrayed in part by the payment of page charges. Under postal regulations, this paper therefore must be hereby marked advertisement solely to indicate this fact.

'To whom reprint requests should be addressed. 1968b; Makhlouf et al., 1989a; Wang, 1977) as experimental material, whereas other studies have used either florets (Aharoni et al., 1985; Makhlouf et al., 1989b; Rushing, 1990) or branchlets (Ballantyne et al., 1988; Lebermann et al., 1968a). Use of florets or branchlets is entirely appropriate for investigating the effects of modified-atmosphere packaging on broccoli senescence, as these are commonly used in this mode of marketing. Florets or branchlets are also highly desirable as model systems for investigating senescence because their smaller size simplifies experimental manipulation and temperature equilibration (broccoli heads can weigh up to $1 \mathrm{~kg}$ and require containers of up to 10 liters). However, because of the potential for interaction between the florets and the tissues of the rest of the head, the development of senescence may be different in broccoli presented as florets, branchlets, or whole heads. We are unaware of any systematic attempts to relate physiological changes accompanying senescence in florets to those that occur in branchlets or whole heads.

In this paper, we describe and compare patterns of respiration, ethylene production, and color change occurring in three broccoli cultivars for florets, branchlets, and heads during postharvest senescence at 20C in darkness, with particular emphasis on changes occurring early after harvest. We also describe and compare patterns of early change in respiratory metabolism and ethylene production occurring in heads of three broccoli cultivars held in the same conditions during the preharvest-postharvest continuum.

\section{Materials and Methods}

Field-harvested broccoli. 'Green Beauty', 'Dominator', and 'Shogun' broccoli plants were grown at Somersby Research Station, New South Wales Dept. of Agriculture and Fisheries, during Fall 1990 using standard commercial practices. At maturity, whole heads were harvested at dawn (5 to 12C), stripped of any remaining leaves, and transported to the laboratory within $1.5 \mathrm{~h}$. Heads were surface-sterilized with $100 \mathrm{ppm} \mathrm{NaOCl}$ as described by Rushing (1990), divided into florets and branchlets as necessary, and placed 
in respiration containers within $2 \mathrm{~h}$ of harvest.

Florets $(\approx 5 \mathrm{~g}$, trimmed from branchlets with a sterile scalpel, as individual floret groups at the point immediately below their attachment to the branchlet), three entire branchlets ( $\approx 40 \mathrm{~g}$ excised where branchlets join the main head axis), and single, entire heads $(\approx 300$ to $400 \mathrm{~g}$ ) were placed in sterilized containers (150- and 550$\mathrm{ml}$ capacity for florets and branchlets respectively, and 10-liter capacity for heads) and stored at 20C in darkness, except for brief periods of light when measurements were being taken. Aeration was provided by a flow-through system of humidified [ $>98 \%$ relative humidity $(\mathrm{RH})]$, ethylene-free air at $1.0,1.5$, and 10 to 30 liters $\cdot \mathrm{h}^{-1}$ for florets, branchlets, and heads, respectively. All floret and branchlet samples were obtained from the second layer of branchlets above the head base. These were considered to represent branchlets of an average size and developmental age on the head. Containers were equilibrated for $1 \mathrm{~h}$ before initial measurements. The higher airflow was used for the 10-liter containers during the equilibration period for 'Dominator' and 'Shogun' before being reduced to 10 liters $\cdot \mathrm{h}^{-1}$. The flow rate for 'Green Beauty' was 10 liters $\cdot \mathrm{h}^{-1}$ throughout. The experiment consisted of five replications of each sample obtained from separate heads.

Carbon dioxide production and $\mathrm{O}_{2}$ consumption were measured periodically by infrared gas analysis (model PIR-2000; Horiba, Tokyo) and paramagnetic oxygen analysis (series 1100; Servomex, Sussex, U.K.) of the outflowing airstream. Ethylene production was measured by injecting 1-ml samples obtained from the outflowing airstream into a gas chromatograph (Loenco, Altadena, Calif.) fitted with a flame ionization detector and a 60- to 80-mesh alumina column, with the injector at $160 \mathrm{C}$ and the column at $180 \mathrm{C}$.

The color of florets of all samples was measured nondestructively at daily intervals by reflectance using a color meter (Chroma meter II; Minolta, Osaka, Japan) with an 8-mm measuring head and D-65 (6504K) illuminant. Reflectance of each replicate was measured on four individual floret groups selected at random, at three equally spaced sites around the circumference of each branchlet, and at four equally spaced sites around the circumference of each head. Reflectance readings for heads were taken on florets located at a similar position on the head to that from which floret and branchlet samples were excised. Results are expressed as hue angle (Shewfelt et al., 1984).

Preharvest-postharvest studies. 'Green Beauty', 'Dominator', and 'Shogun' broccoli were seeded into speedling trays on 8 Feb. 1990. On 22 Mar., seedlings were transplanted into 20-liter plastic pots filled with a medium containing 1 perlite : 1 vermiculite : 4 peat (by volume), $100 \mathrm{~g}$ dolomite, $40 \mathrm{~g}$ Osmocote $(18 \mathrm{~N}-2.6 \mathrm{P}-$ 10K; Sierra Chemical Co., New S. Wales), and $2 \mathrm{~g}$ trace elements (Hortico, New S. Wales). Plants were grown outside over late fallearly winter and watered with tap water as required. When heads reached the physiological stage of maturity necessary for commercial marketing (head size 58 to $112 \mathrm{~g}$, 'Green Beauty'; 113 to 188 g, 'Dominator'; 112 to $166 \mathrm{~g}$, 'Shogun'), plants were prepared for physiological experiments as described below.

Individual broccoli plants grown in pots were stripped of leaves and transferred to a 20C constant-temperature room. A small strip of pliable adhesive putty (Blutack; Bostic, Emhart, Victoria, Australia) was placed around the irregularly shaped main axis just below the head cluster and above any leaf scars to exclude wounded tissue from the measurements (Fig. 1). Heads were then enclosed in low-density polyethylene ( $45 \mu \mathrm{m}$ thick) bags fitted with inlet and outlet gas ports (Swinnex-13 filter holders with filter removed; Millipore, Milford, Mass.). Bags were sealed by enclosing the base of the bag around the rubber adhesive with a rubber band. The entire bagged head of the plant and the main stem axis

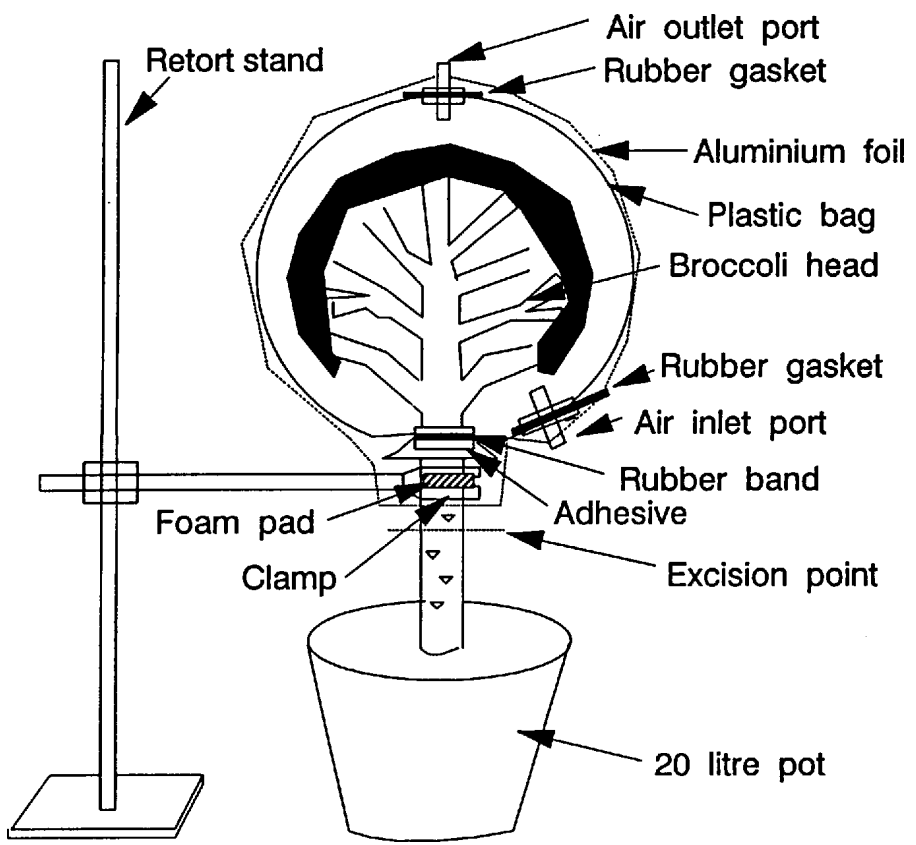

Fig. 1. Apparatus for measuring pre- and postharvest respiratory and ethylene changes of broccoli heads.

down to the potting mix were enclosed in aluminum foil to continuously exclude light from the plants. The main axis was supported by a retort stand and clamp attached to the stem. A foamrubber cushion was used under the clamp to avoid compression damage to the plant.

Aeration of the enclosed heads was provided by a flow-through system of humidified (>98\% RH), ethylene-free air at 3 to 10 liters $\cdot \mathrm{h}^{-1}$ (two to five air changes per hour). Preliminary experiments showed that leakage of $\mathrm{CO}_{2}$ through the bag was insignificant under these conditions. Plants were equilibrated in the system overnight before measurements began. Postharvest experiments were initiated by gently cutting the stem and leaving the head supported by the retort stand. Six heads of each cultivar were used in the experiments. Carbon dioxide production, $\mathrm{O}_{2}$ consumption, and ethylene production were measured hourly for $3 \mathrm{~h}$ preharvest, immediately before cutting the head from the stem, and periodically after harvest, as described above.

\section{Results}

Field-harvested broccoli. Carbon dioxide production was very high initially for all broccoli samples $\left(<1250 \mathrm{mg} \cdot \mathrm{kg}^{-1} \cdot \mathrm{h}^{-1}\right.$ for florets). These levels rapidly declined during the next $12 \mathrm{~h}$ before stabilizing at $50 \%$ of the initial rate (Fig. 2). A consistent postharvest respiratory pattern was observed for florets, branchlets, and heads. Respiration was highest for florets and lowest for whole heads. Due to slight differences in growth rate between cultivars, 'Green Beauty' matured 5 days before 'Dominator' and 'Shogun'. The day 'Green Beauty' was harvested was several degrees warmer than the day 'Dominator' and 'Shogun' were harvested. Since transfer to the laboratory and placement in the respiration jars was rapid, whole heads of these two cultivars had not reached temperature equilibrium during the hour allowed before the first measurement.

Respiratory quotients (RQs) for 'Dominator' and 'Shogun' branchlets and heads declined rapidly after harvest, before stabilizing at $48 \mathrm{~h}$ (Fig. 3). This trend was less apparent for 'Green 


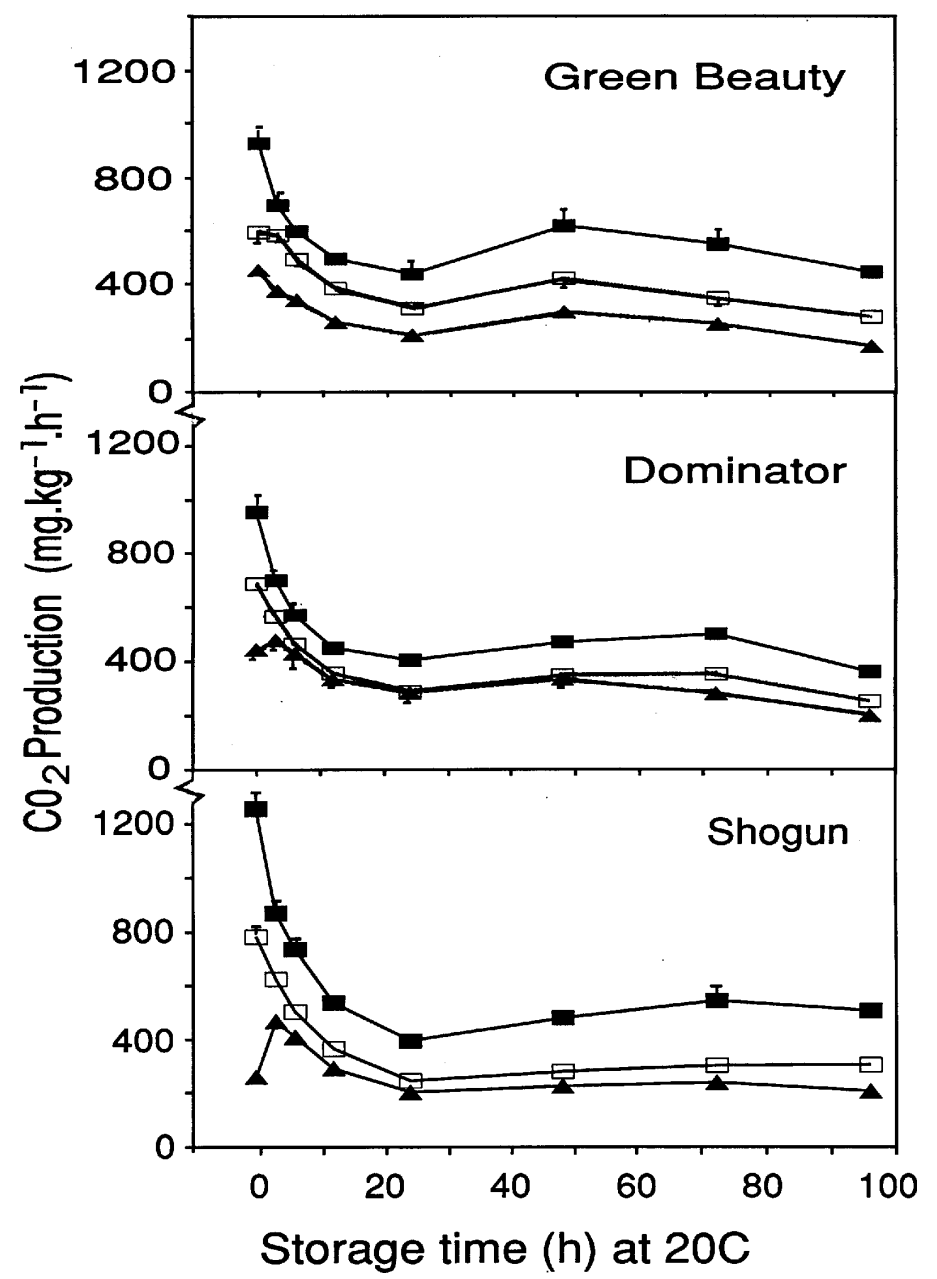

Fig. 2. Changes in $\mathrm{CO}_{2}$ production of three broccoli cultivars during storage at 20C. (ם) Florets; $(\square)$ branchlets; $(\boldsymbol{\Delta})$ heads. Bars are sEs and are contained within the symbols when not shown.

Beauty'. Florets behaved differently, particularly during the first $48 \mathrm{~h}$. The RQs of 'Shogun' and 'Dominator' florets remained >1.0 during this period, and even increased in the case of 'Green Beauty' during the first $24 \mathrm{~h}$. Use of different substrates for respiration by isolated florets compared with branchlets and heads could account for this result.

Ethylene production pattern varied with cultivar (Fig. 4). Ethylene production rapidly increased for 'Green Beauty' and 'Dominator' between 0 and $6 \mathrm{~h}$ and then declined to basal levels by $12 \mathrm{~h}$. 'Shogun' did not exhibit a large increase in ethylene production at $3 \mathrm{~h}$ characteristic of the other cultivars, and also produced $50 \%$ less basal ethylene than the others. Florets, branchlets, and heads generally behaved similarly except that ethylene production by florets increased between 48 and $96 \mathrm{~h}$ for 'Green Beauty' and 'Dominator'. Florets tended to produce more ethylene than branchlets or heads.

The first change in color became apparent between 48 and $72 \mathrm{~h}$, especially for 'Green Beauty' and 'Dominator' (Fig. 5). 'Shogun' florets and branchlets yellowed between 72 and $96 \mathrm{~h}$. All florets, branchlets, and heads had substantially yellow florets by $96 \mathrm{~h}$. Some differences between the samples was detected, with florets and branchlets lagging behind whole heads by $12 \mathrm{~h}$ for 'Green Beauty' and 'Dominator' and $24 \mathrm{~h}$ for 'Shogun'.

Preharvest-postharvest studies. In the previous experiment, there was a short delay between harvest and the first measurements. Also, temperature equilibration was a problem, particularly

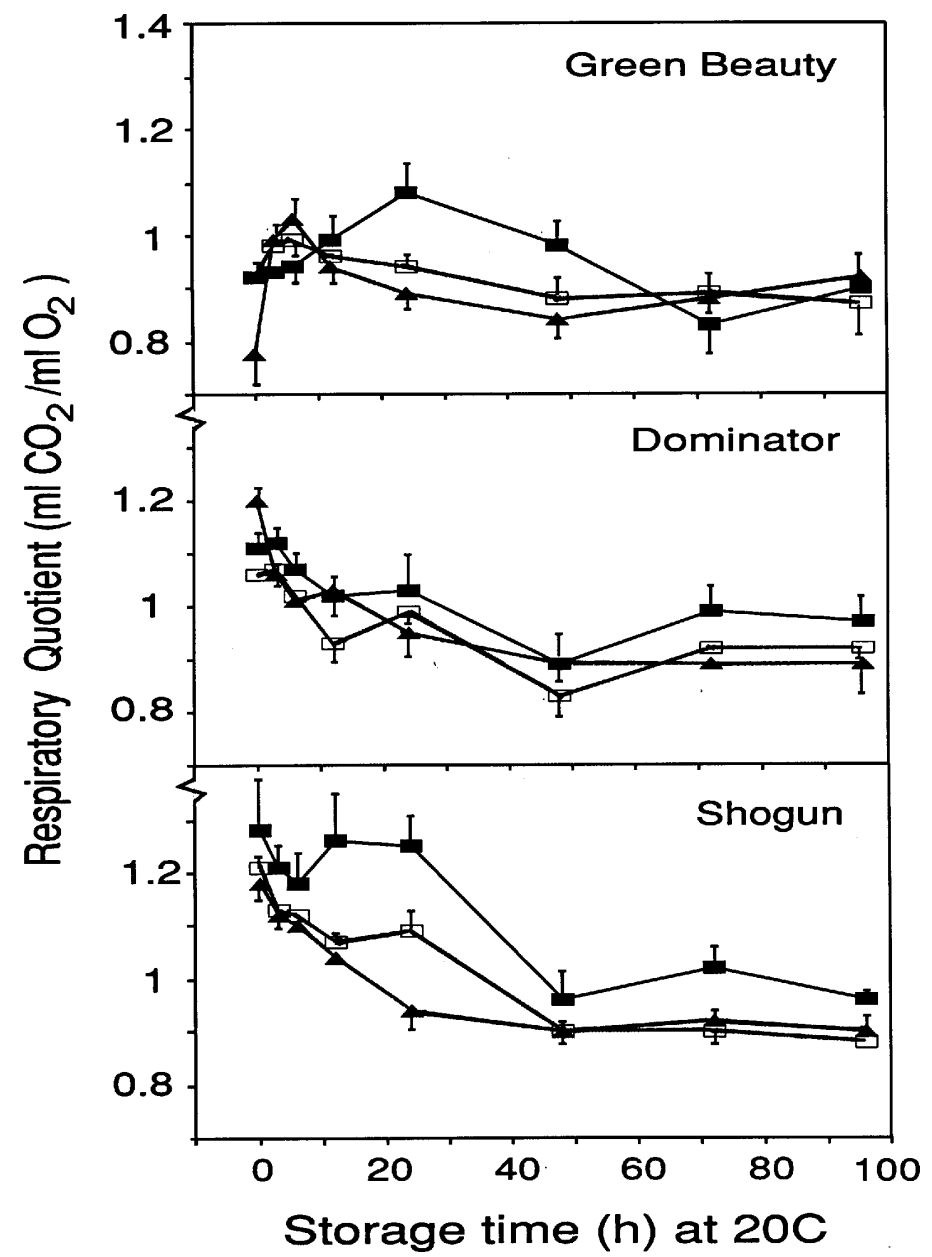

Fig. 3. Changes in respiratory quotient of three broccoli cultivars during storage at 20C. ( $\mathbf{\square})$ Florets; ( $\boldsymbol{\square})$ branchlets; $(\boldsymbol{\Delta})$ heads. Bars are sEs and are contained within the symbols when not shown.

for the first measurement of whole heads taken after harvest on a cold morning. For these reasons, and more particularly to investigate respiration and ethylene production during the preharvestpostharvest continuum, a system was devised (Fig. 1) to measure changes in $\mathrm{CO}_{2}$ and ethylene production and RQs with container-grown broccoli plants. Carbon dioxide and ethylene production and RQs of heads of all three cultivars were relatively stable during the preharvest period (Fig. 6). Carbon dioxide produced by 'Dominator' and 'Shogun' heads declined within $3 \mathrm{~h}$ of harvest and stabilized at $12 \mathrm{~h}$. 'Green Beauty' heads varied more in their initial rate of $\mathrm{CO}_{2}$ production than those of the other cultivars. However, a declining postharvest trend in $\mathrm{CO}_{2}$ production was consistently recorded for each enclosed head.

'Shogun' heads produced $\mathrm{CO}_{2}$ at a higher rate initially than either 'Green Beauty' or 'Dominator'. However, rates of $\mathrm{CO}_{2}$ production by heads of all three cultivars were similar by $24 \mathrm{~h}$ after harvest (Fig. 6). The stable level of $\mathrm{CO}_{2}$ production at $24 \mathrm{~h}$ was similar to rates determined for the three cultivars from field-harvested material.

RQs of all three cultivars generally followed the declining postharvest trend in $\mathrm{CO}_{2}$ production (Fig. 6). The initial RQs for all cultivars were variable, but the declining trend was consistent. Ethylene production of 'Dominator' and 'Shogun' heads was unchanged throughout the preharvest-postharvest continuum(Fig. 6). 'Green Beauty' heads tended to increase ethylene production continuously after harvest, up to a 4-fold increase over preharvest 


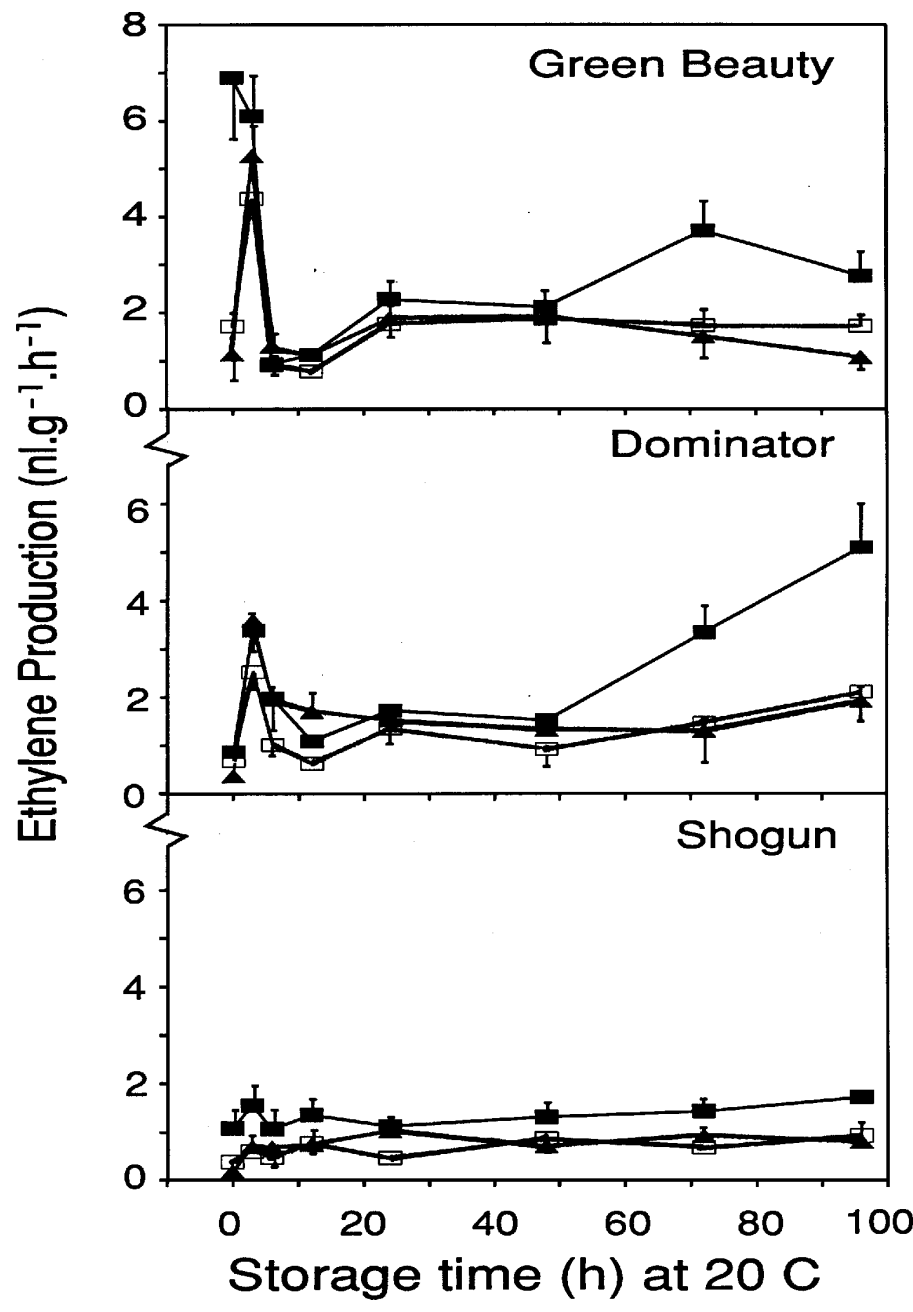

Fig. 4. Changes in ethylene production of three broccoli cultivars during storage at 20C. ( $\square$ ) Florets; $(\square)$ branchlets; ( $\boldsymbol{\Delta})$ heads. Bars are sEs and are contained within the symbols when not shown.

levels at $24 \mathrm{~h}$ postharvest. Please, note that the experimental design necessitated the exposure of the portion of the stem that was cut to harvest the broccoli, excluding measurement of any wound ethylene produced from this surface.

\section{Discussion}

A comparison of the early postharvest changes in field-harvested and container-grown broccoli showed some differences in $\mathrm{CO}_{2}$ and ethylene production. The higher initial rate of $\mathrm{CO}_{2}$ production by heads of all three cultivars using field-harvested broccoli most probably reflects the stress imposed by harvest, trimming, transportation, and washing procedures. The precautions taken, using container-grown plants to avoid stress, allow a more accurate interpretation of physiological changes during the transition from attached to detached to be obtained.

After $3 \mathrm{~h}$ at 20C, heads of field-harvested 'Green Beauty' and 'Dominator' broccoli had a marked transient increase in ethylene production, which was not detected in the container-grown broccoli after harvest. This difference probably also reflects the lower stress imposed on container-grown heads compared to field-harvested heads.

Despite these differences, some consistent trends in the pattern of $\mathrm{CO}_{2}$ production and $\mathrm{RQs}$ were found in all experiments. The rate of $\mathrm{CO}_{2}$ production declined in florets, branchlets, and heads during

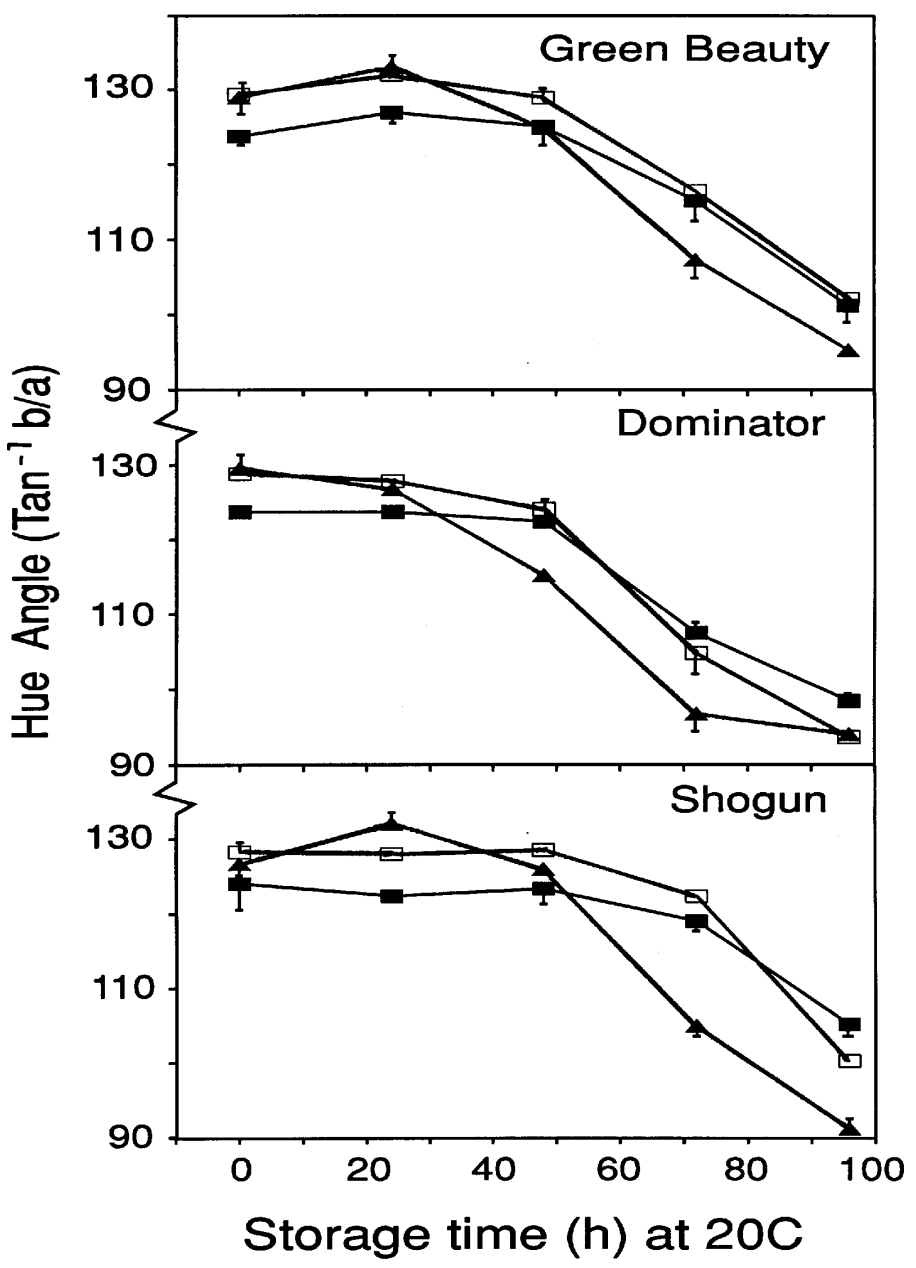

Fig. 5. Color change of florets of three broccoli cultivars during storage at 20C. ( Florets; ( $\boldsymbol{\square})$ branchlets; $(\boldsymbol{\Delta})$ heads. Bars are sEs and are contained within the symbols when not shown.

the first $12 \mathrm{~h}$. Rushing (1990) also found a decline in $\mathrm{CO}_{2}$ production of 'Citation' broccoli branchlets after $24 \mathrm{~h}$ at $16 \mathrm{C}$, with initial measurements taken early after harvest. These findings contrast with all other broccoli-senescence studies, which have described either a stable or climacteric-like increase in respiration during storage after harvest at temperatures near ambient (Aharoni et al., 1985; MacLean et al., 1963; Makhlouf et al., 1989a; Wang, 1977). However, these studies used broccoli of undefined age, or heads that had been stored for at least $16 \mathrm{~h}$ or subjected to other postharvest treatments (e.g., top-icing) before the initial measurements were completed. In these situations, very early respiratory changes may be modified or not detected.

A decline in respiration rate after harvest has previously been described in various vegetables (King et al., 1990; Lill et al., 1990; Platenius, 1942) and several cut flowers (Coorts, 1973; Trippi and Paulin, 1984). However, the physiological reason for this respiratory decline is unknown. The collective evidence of a declining rate of $\mathrm{CO}_{2}$ production and a parallel change in RQs of broccoli tissues early after harvest suggests that the tissues may rely on respiratory substrates or respiratory control factors translocated from other tissues from which the head is separated at harvest, e.g., leaves or roots. Our data are consistent with hypotheses linking changes in the production and use of cellular energy with the onset of senescence (Trippi and Paulin, 1984).

Ethylene production of heads of container-grown 'Dominator' and 'Shogun' broccoli was unchanged throughout the preharvest- 


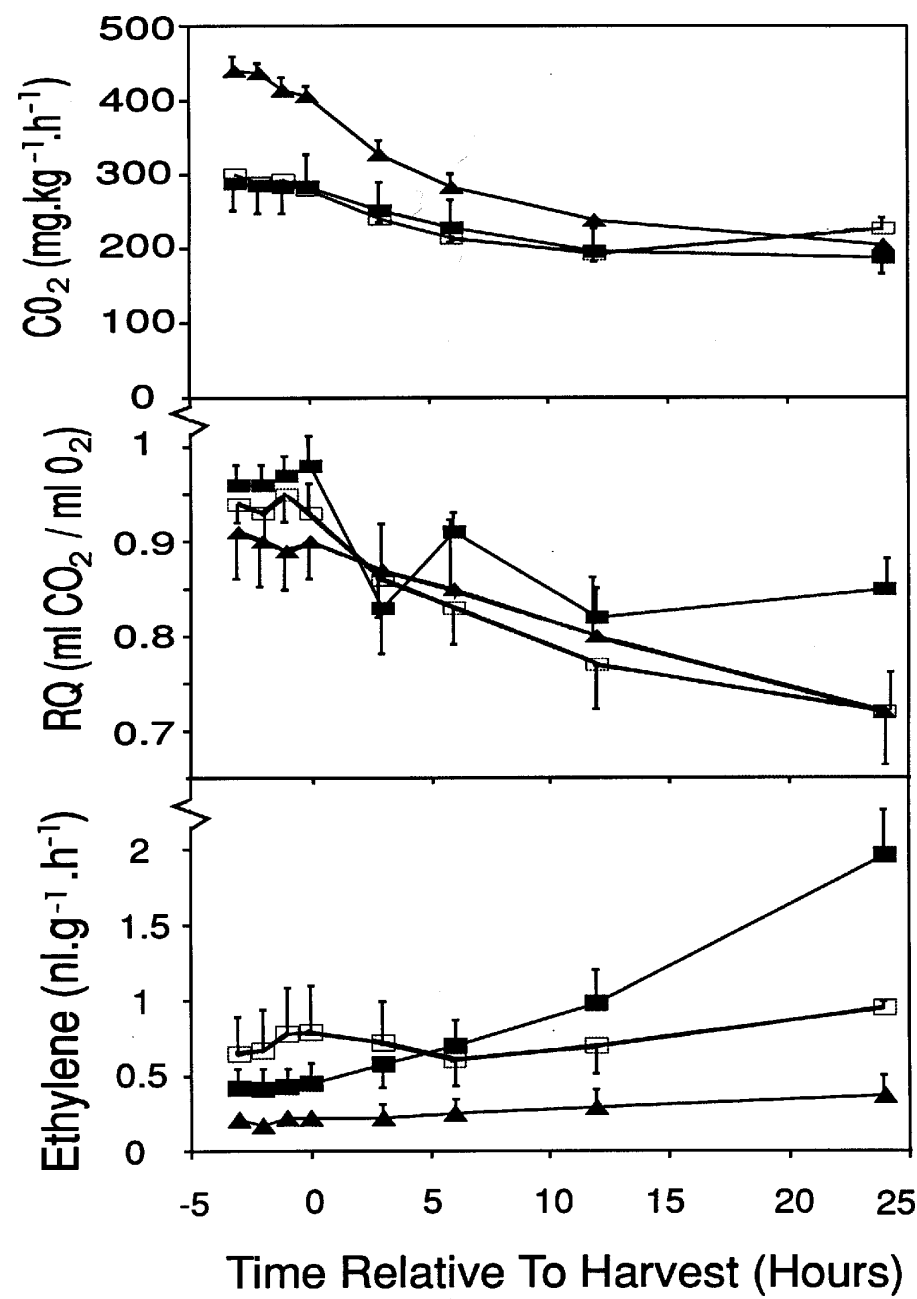

Fig. 6. Changes in $\mathrm{CO}_{2}$ production, respiratory quotients, and ethylene production of $(\boldsymbol{\square})$ 'Green Beauty', ( $\square)$ 'Dominator', and ( $\boldsymbol{\Delta})$ 'Shogun' broccoli heads during pre- and postharvest storage at 20C. Heads were cut from the plant at time zero. Bars are SEs and are contained within the symbols when not shown.

postharvest continuum, whereas that of 'Green Beauty' heads increased continuously after harvest. This result suggests that 'Green Beauty' heads are more sensitive to the perturbations of harvest, or acquire the ability to produce stress ethylene earlier, than the other cultivars.

Florets produced more $\mathrm{CO}_{2}$ and tended to produce more ethylene than branchlets or heads. The high level of $\mathrm{CO}_{2}$ production reflects the developmental state of the florets, as they comprise immature and rapidly developing tissue and, possibly, a lower water content. Aharoni et al. (1985) found that florets of 'Green Duke' broccoli also produced more ethylene than heads in a climacteric-like manner. This led them to conclude that the flower buds rather than the surrounding vegetative tissues are responsible for most of the ethylene produced. Makhlouf et al. (1989b) have also described a climacteric-like pattern of ethylene production by 'Green Valiant' broccoli florets during storage at 25C. While we found no consistent evidence of a climacteric-like increase in respiration and ethylene production in these experiments, our results may have been influenced by the amount of vegetative tissue present in our samples. Studies of ethylene responses by isolated sepals and reproductive structures may yield more conclusive ethylene production data (Tian et al., 1994).

The onset of yellowing of broccoli florets (Fig. 5) bore no consistent relationship to changes in ethylene production during storage (Fig. 4). However, time until onset of yellowing was broadly related to the basal levels of ethylene produced by each cultivar, with the rate of 'Green Beauty' being marginally higher than that of 'Dominator' and those of both being considerably higher than that of 'Shogun'. Exogenous ethylene hastens yellowing of broccoli florets (Aharoni et al., 1985), whereas anti-ethylene agents delay yellowing (Aharoni et al., 1985; Wang, 1977). Collectively, these observations suggest that broccoli florets are sensitive to ethylene. It is possible that a change in sensitivity of florets to ethylene rather than changes in endogenous ethylene production per se regulate yellowing.

These studies have demonstrated changes in respiratory metabolism early after harvest in field-harvested and container-grown broccoli. Florets, branchlets, and heads of 'Green Beauty' and 'Dominator' broccoli follow similar patterns of postharvest change in respiratory metabolism and color during storage at 20C. 'Shogun' florets, branchlets, and heads followed a similar respiratory pattern to those of 'Green Beauty' and 'Dominator', but tended to yellow slightly later. The high variability recorded in floret RQs suggests that florets would not make good models for investigating early changes accompanying postharvest broccoli senescence. However, using branchlets seems to be a useful alternative to using whole heads in such experiments.

\section{Literature Cited}

Aharoni, N., S. Philosoph-Hadas, and R. Barkai-Golan. 1985. Modified atmospheres to delay senescence and decay of broccoli. Proc. 4th Natl. Controlled Atmosphere Conf., Dept. of Hort. Sci., Raleigh, N.C. Hort. Rpt. 126:169-177.

Ballantyne, A., R. Stark, and J.D. Selman. 1988. Modified atmosphere packaging of broccoli florets. Intl. Food Sci. Technol. 23:353-360.

Brennan, P.S. and R.L. Shewfelt. 1989. Effect of cooling delay at harvest on broccoli quality during postharvest storage. J. Food Quality. 12:1322.

Coorts, G.D. 1973. Internal metabolic changes in cut flowers. HortScience 8:195-198.

Davies, K.M. and G.A. King. 1993. Isolation and characterization of a cDNA clone for a harvest-induced asparagine synthetase from Asparagus officinalis L. Plant Physiol. 102:1337-1340.

Dedolph, R.R., S.H. Wittwer, and H.E. Larzelere. 1963. Consumer verification of quality maintenance induced by $\mathrm{N}^{6}$-benzyladenine in the storage of celery (Apium graveolens) and broccoli (Brassica oleracea var Italica). Food Technol. 17:1323-1324.

Hurst, P.L., G.A. King, D.C. Woollard, and W.M. Borst. 1993. Nitrogen metabolism in harvested asparagus: No difference between light and dark storage at 20C. Food Chem. 47:329-332.

Kasmire, R.F., A.A. Kader, and J.A. Klaustermeyer. 1974. Influence of aeration rate and atmospheric composition during simulated transit on visual quality and off-odour production of broccoli. HortScience 9:228229.

King, G.A., D.C. Woollard, D.E. Irving, and W.M. Borst. 1990. Physiological changes in asparagus spear tips after harvest. Physiol. Plant. 80:393-400.

Lebermann, K.W., A.I. Nelson, and M.P. Steinberg. 1968a. Postharvest changes of broccoli stored in modified atmospheres. II. Acidity and its influence on texture and chlorophyll retention of the branchlets. Food Technol. 22:490-493.

Lebermann, K.W., A.I. Nelson, and M.P. Steinberg. 1968b. Postharvest changes of broccoli stored in modified atmospheres. I. Respiration of shoots and colour of flower heads. Food Technol. 22:487-490.

Lill, R.E., G.A. King, and E.M. O’Donoghue. 1990. Physiological changes in asparagus spears immediately after harvest. Scientia Hort. 44:191-199.

MacLean, D.C., R.R. Dedolph, and S.H. Wittwer. 1963. Respiratory responses of broccoli (Brassica oleracea var. Italica) to pre- and post-harvest treatments with $\mathrm{N}^{6}$-benzyladenine. Proc. Amer. Soc. Hort. 
Sci. 83:484-487.

Makhlouf, J., F. Castaigne, J. Arul, C. Willemot, and A. Gosselin. 1989a. Long-term storage of broccoli under controlled atmosphere. HortScience 24:637-639.

Makhlouf, J., C. Willemot, J. Arul, F. Castaigne, and J.P. Emond. 1989b. Regulation of ethylene biosynthesis in broccoli flower buds in controlled atmospheres. J. Amer. Soc. Hort. Sci. 114:955-959.

Platenius, H. 1942. Effect of temperature on the respiration rate and the respiratory quotient of some vegetables. Plant Physiol. 17:179-187.

Rushing, J.W. 1990. Cytokinins affect respiration, ethylene production, and chlorophyll retention of packaged broccoli florets. HortScience 25:88-90.

Shewfelt, R.L., E.K. Eaton, and K.M. Batal. 1984. Nondestructive colour measurement of fresh broccoli. J. Food Sci. 49:1612-1613.

Tian, M.S., C.G. Downs, R.E. Lill, and G.A. King. 1994. A role for ethylene in the yellowing of broccoli after harvest. J. Amer. Soc. Hort. Sci. 119:276-281.

Trippi, V.S. and A. Paulin. 1984. The senescence of cut carnation: A phasic phenomenon. Physiol. Plant. 60:221-226.

Wang, C.Y. 1977. Effect of aminoethoxy analog of rhizobitoxine and sodium benzoate on senescence of broccoli. HortScience 12:54-56. 